\title{
なだれの発生率について
}

高橋三郎·木全敬蔵·田代征雄

\section{The Probability of Occurrence of the Avalanche}

\author{
by Saburo Takahashi, Keiyo Kimata \\ and Tadao Tashiro
}

\begin{abstract}
As the fixed elements of occurrence of the avalanche, the authors defined vegetation, degrees of inclination, direction and type of the slopes which are able to measure or interprete mith non-snow covered aerial photos. patterns.

Using these elements, every slope which is devided by ridge and drainage classified 84

With snow covered aerial photos interpreted avalanches, and then calculated the statistical probability of occurrence of the avalanche for every pattern.

If such fixed elements are able to measure or interprete, the probability of the occurrence of the avalanche would be estimated at everywhere by means of this result.

無雪期の航空写真から測定または判読できるなだれ発生斜面の固定因子として植生，傾斜，方位， 斜面形をとりあげ，陵線と谷線で区分した単位斜面を分類し，84 のパタンになとめた。

積雪期の航空写真からなだれを判読し，84のパタンおの打のについて，なだれが発生した確率を 求めた。

この確率を使って固定因子を判読または測定できれば, 積雪深に応じたなだれの発生率を計算す ることができる。
\end{abstract}

\section{I. まえがき}

上越国道工事事務所では, 国道 17 号線に沿って, 毎年積雪期の航空写真を撮影してきた。昭和 41 年度 までは, 航空写真を判読・解析して雪崩分布図を作成 するだけに使われていたが，本年を含めて，場所によ っては4 ケ年分の資料が蓄積されたので，観点をかえ て航空写真から得られる情報を集計し，雪崩が発生す る確率を算出し, その結果を, 国道 17 号沿いの地域 にとどまらず，他の積雪地带にも応用しょうという試 みの第一段階として解析したものである。

判読は, 木全敬蔵, 計算のシステムは, 高橋三郎, プログラミングと計算は, 田代征雄がそれぞれ担当し た。

\section{II. 雪崩発生要素}

雪崩発生の要素として, 降雪量, 積雪量, 気温, 日 照量等の気象条件と地表面の傾斜角, 斜面の形, 斜面 の向き，植生等の地形的な条件の 2 つた別される。 後者は固定的で, 同一地域を覆う無雪期の航空写真

* 東洋航空事業株式会社 Toyokoku Jigyo Co. Ltd.

$\lceil$ 写真測量」Vol. 7 No. 31968
があればほほぼ完全に読みとることができる。 航空写真は. 撮影時点の情報を写しているにすぎな いから, 航空写真による解析では, 気象条件すなわち 時間で変動する要素は取报うことはできない。しかし， 今回の調査地域が上越国境付近に限られているところ からマクロ的に見て，気象条件は同じであると見なす ことにした。したがって，雪崩発生の確率を考える場 合, 調査範囲が限定されていれば，積雪量を除く他の 気象条件を捨象して, 固定要素のみで計算しても, 結 果は有効であるという仮定をとった。

調査地域の斜面を稜線，谷線を基準に区分し，その 区分された斜面を単位に，傾斜，方位，斜面形，植生 の固定要素と, 変動要素の積雪深を航空写真または分 布図から読みとっておき，次に積雪期航空写真を判読 して単位斜面毎に雪崩があるか，ないかを調べる。

調査の結果を整理して, 同一の固定要素をもつ斜面 毎に一つのグループにまとめる。それぞれのグループ の中で, 雪崩が写っている（航空写真に雪崩が写って いる) 斜面の数と, 雪崩が起きていない斜面の数, (積 雪期航空写真が 4 ケ年分あれば，1つの斜面を同一要 素をもつ4つの斜面として扱う。で統解的な確率が求 められる。さらに, その数を積雪量に応じて分類した 
のち計算すれば，積雪量に応じた斜面每の雪崩生の確 率が得られる。

\section{1) 国定要素の判断}

(1) 傾 斜

斜面の傾斜は地形図から読みとった。この場合どこ をとるかが問題であるが，今回は，単位斜面内での中 央附近で，しか子雪崩が発生している部分，あるいは 発生しそうなケ所で，かつ，最も等高線の混んでい るところの 2 本の計曲線に挾まれた距離を測り， $\theta=$ $\tan ^{-1} 5 n / \alpha$ (ただし， $\alpha ; 2$ 本の計曲線間隔， $n$ ；等高 線間隔）求めた。

() 斜面形

斜面形の分類法は，門村氏の法を参考にした。す なわち単位斜面を水平断面，縦断面，平面に投影した ときの形により，断面形については，凸形，凹形，直 線形, 凹山の複合形の 4 種, 平面形については, 末端 で拡がっている末拡がり形，その逆の末つぼみ形，ま たそれらの複合形に分類した。

どの斜面にも多少の凹凸はあり，㛜密に言えば，こ れらの区分ではすべて複合形に分類されてしまうが， 細い凹凸は無視し，全体の形から判定した。

(i) 方 位

斜面の方法は，最大傾斜方向を 8 万位であらわした。

(二) 植 生

斜面の植生の分類は, 裸地または草地, 灌木, 森林 の 3 分類とし, 混在する場合は最子優越するものにし た。

\section{2）雪崩の判読}

雪崩の判読全層雪崩は, 地肌が黒く出ているので, 容易に判読できるが，表層雪崩は注意を要する。底に デブリがある場合は，発生面（あるいは点）からデブ リ末端に至るまで明瞭な摖痕模様が流跡として残って いるので, 追跡できる。明膫な擦痕模様はないが，周 囲の雪面と比べて晎った肌理をしているところを 2〜 3 倍の拡大写真で観察すると, 僅かに模様が読みとれ る場合がある。また立体観察をすることにより，僅か ながら比高があることなどから表層雪崩があったと判 定する。

\section{III. 雪崩発生危険率の計算の方法}

雪崩発生の原因は, 前章に示した $5 つ 0$ 要素に区分 して考えることにするが，実際にこれらが個々に作用 して, 雪崩が起り, あるいは, 起きないという事象が 生ずるというのではなく，これらが統合されて始めて 雪崩が起る。あるいは起きないという事象が生ずるの である。

例えば, 積雪深 $5 \mathrm{~m}$ という条件だけは, 雪崩発生
危険率が メ\%という計算はできなく，他の条件が揃 っていなければならない。この場合，他のすべての条 件が一定なら，積雪深に応じて雪崩発生の割合が一定 だあると仮定する。この仮定は，計算を簡単にするた めにとったもので, 将来データが増加し，より複雑な 計算処理ができるようになったとき仮定をより真に近 いと思われる方向に近づけることが望ましい。

\section{1）各要素の階級区分}

積雪深と斜面の傾斜は定量的に表現されているので, 頻洨分布により階級区分が可能であるが，斜面形，斜 面の方位, 植生は定性的であるので, その階級区分は 门日本鉄道施設協会：なだれ発生に対する航空写真読 法の研究報告書, 昭和 40 年 3 月 31 日」に拠った。

この報告書に,なだれ発生地点におけるなだれ地点 の形, 長さ, 面積等について, 斜面の傾斜, 方位, 山 稜線の走向，なだれ地点の高度，斜面形（水平断面形， 縦断面形）地形上の位置, 植生, 地表の地質の各階級 值に対し，なだれ発生の頻度が報告されているので， 谷要素の中の項目を頻度数で区分し，その階級值をつ けた。はじめは, 各要素とも8階級を採ったが, 標本 の数が少なく, 全く標本のない組合わせがいくつか出 米て，8階級に区分した意味がなくなったので, 思い切 って, 各要素 3 階級(ただ積雪深のみ 4 階級)とした。

\section{表 III-1 A 積雪深の階級区分}

$i=1,2$. 3. 4 .

\begin{tabular}{|c|c|c|c|}
\hline 階 級 & 積 & 雪 & 深 \\
\hline 1 & $1 \mathrm{~m}$ 以上 & & $2 \mathrm{~m}$ 末満 \\
\hline 2 & $2 \mathrm{~m}$ 以上 & & $3 \mathrm{~m}$ 末满 \\
\hline 3 & $3 \mathrm{~m}$ 以上 & & $4 \mathrm{~m}$ 末满 \\
\hline 4 & $4 \mathrm{~m}$ 以上 & & \\
\hline
\end{tabular}

\section{表III-2 B 傾斜の階級区分}

$i=1$. 2. 3 .

\begin{tabular}{|c|cc|}
\hline 階 級 & 傾 & 斜 \\
\hline 1 & $30^{\circ}$ 未満 & \\
2 & $30^{\circ}$ 以上 & $40^{\circ}$ 末満 \\
3 & $40^{\circ}$ 以上 & \\
\hline
\end{tabular}

\section{表 III-3 C 斜面形の階級区分}

$i=1$. 2. 3 .

\begin{tabular}{|c|c|c|c|c|c|c|c|c|c|c|c|c|c|c|}
\hline 水平断面 & \multicolumn{3}{|c|}{ 凹 } & \multicolumn{4}{|c|}{ 凸 } & \multicolumn{4}{|c|}{ 等 } & \multicolumn{3}{|c|}{ 複 合 } \\
\hline 面形 & Ш & & & & & & & & & & & & & 等複 \\
\hline 末つぼみ & 1 & & & 3 & 3 & & 3 & 3 & 3 & 3 & 2 & 3 & & 3 \\
\hline ろがり & 1 & & & 3 & 3 & & 3 & 1 & 2 & 1 & 3 & 3 & 3 & 32 \\
\hline 合 & 2 & 1 & 3 & 3 & 3 & 33 & & 3 & 3 & 2 & 2 & 3 & 3 & 31 \\
\hline
\end{tabular}


表III-4 D 方位の階級区分

$i=1$. 2. 3 .

\begin{tabular}{|c|c|c|c|c|c|}
\hline 階 級 & 斜 & 面 & の & 方 & 位 \\
\hline 1 & \multicolumn{5}{|c|}{$\mathrm{W}|| \mathrm{SW}|| \mathrm{NW}$} \\
\hline 2 & \multicolumn{5}{|c|}{$\mathrm{S}|| \mathrm{SE}|| \mathrm{N}$} \\
\hline 3 & \multicolumn{3}{|c|}{$\mathrm{E} \mid \mathrm{NE}$} & & \\
\hline
\end{tabular}

\section{表 III -5 $\quad \mathrm{E} \quad$ 植生の階級区分}

$i=1$. 2. 3 .

\begin{tabular}{|c|cc|}
\hline 階 級 & 植 & 生 \\
\hline 1 & 裸 地 & 草 地 \\
2 & 灌 木 & \\
3 & 森 林 & \\
\hline
\end{tabular}

\section{2) 計算の式}

雪崩発生の要素 $\mathrm{A}(\mathrm{I}), \mathrm{B}(\mathrm{J}), \mathrm{C}(\mathrm{K}), \mathrm{D}(\mathrm{L}), \mathrm{E}(\mathrm{M})$ の個々の他の要素に無関係な雪崩発生の確率を $\mathrm{PA}$ (I), $\mathrm{PB}(\mathrm{J}), \mathrm{PC}(\mathrm{K}), \mathrm{PD}(\mathrm{L}), \mathrm{PE}(\mathrm{M})$ とすると，それ らの組合わせによる確率 (PIJKLM とする) は次の 式による。

$\mathrm{PIJKLM}=\mathrm{PA}(\mathrm{I}), \mathrm{PB}(\mathrm{J}), \mathrm{PC}(\mathrm{K}), \mathrm{PD}(\mathrm{L}), \mathrm{PE}(\mathrm{M})$

PA(I) は記号にすぎないが，PIJKLM は調査結果 により計算できる。

雪崩が発生した場合 1 , 発生していない場合 0 とし て集計する。その結果を TIJKLM とし, 発生, 未発 生の総数を SIJKLM とする。

\section{PIJKLM=TIJKLM/SIJKLM}

標本が, 要素 $A, B$ ……等の各階級で等密度に分布 し,かつ頻度が相当数あれば理想的であるが, A, B ….... 等の各組合わせによっては, 標本が出現しないものも かなりある。また，頻度数が 1 の場合，あるいは非常 に少いことがある。頻度数が 1 の場合, 雪崩が起きる 起きないのいづれかで, 確率が 1 または 0 と両極端に なるようなことになる。このような值は統計上無意味 であるし，捨てるとしても，どの程度の頻度数までを 捨てるかの問題があるいと，頻度数 1 の場合でも，事 実を示すものとして統計上貴重なデータなので何らか の形で利用したい。そこで次のように計算した。

I=1 の場合のすべての TIJKLM の和と SIJKLM の総和をとる。

$$
\mathrm{PA}(1)=\sum^{4} \mathrm{~T} 1 \mathrm{JKLM} / \Sigma^{4} \mathrm{~S} 1 \mathrm{JKLM}
$$

この $\mathrm{S}$ はかなりの数になるのである程度安定した 数値となる。

I が 2,3,4 についても同じように求める。

一般式は
$\mathrm{PA} \dot{\mathrm{I}}=\sum^{4} \mathrm{~T} \dot{\mathrm{I} J K L M} / \sum^{4} \mathrm{SIJJKLM}$

この $\overline{\mathrm{PAI}}$ は次のような性質があると考えられる。 $\overline{\mathrm{PA} 1}: \overline{\mathrm{PA} 2}: \overline{\mathrm{PA} 3}: \overline{\mathrm{PA} 4}=\mathrm{PA}(1): \mathrm{PA}(2):$

$$
\mathrm{PA}(3): \mathrm{PA}(4)
$$

$$
\begin{aligned}
\overline{\mathrm{PA} 1} / \mathrm{PA}(1) & =\overline{\mathrm{PA} 2} / \mathrm{PA}(2)=\overline{\mathrm{PA} 3} / \mathrm{PA}(3) \\
& =\overline{\mathrm{PA}} 4 / \mathrm{PA}(4)=\frac{1}{\mathrm{KA}}
\end{aligned}
$$

$\mathrm{KA}$ は $\mathrm{A}$ につての比例定数である。

同様にして, $\overline{\mathrm{PBJ}}, \overline{\mathrm{PCK}} \cdots \cdots . . . \mathrm{KB}, \mathrm{KC} \cdots \cdots .$. 等が計 算される。

$\overline{\mathrm{PBJ}}, \overline{\mathrm{PCK}} \cdot \cdots . .$. 等は計算され, ある数值をとる。 $\mathrm{KB}, \mathrm{KC} \cdot \cdots \cdot .$. 等は最後まで記号として残る。(KA, KB ……等は個々には計算の必要はない。)

PAI は A についての周辺分布といわれる。Iにつ てだいたい此例するとみなしたのであるが，I が変る と, I 以外の条件が変ってくるので, 完全に比例する とは限らないのであるが一応比例するものとした。も しあまりに差があるなら，計算された $\mathrm{PA}(\mathrm{I}), \mathrm{PA}(\mathrm{J})$ 等を再び PAI, ……沶いて繰返し計算すれば，さら に求める $\mathrm{PA}(\mathrm{I}), \mathrm{PA}(\mathrm{J})$ 等に近いものが得られると 考えられる。

以上によって得られた $\overline{\mathrm{PBI}}$ 等によって, PA(I) ...... 等を求めるには

$$
\begin{aligned}
& \mathrm{PA}(\dot{\mathrm{I}}) \cdot \mathrm{PB}(\mathrm{J}) \cdot \mathrm{PC}(\mathrm{K}) \cdot \mathrm{PD}(\mathrm{L}) \cdot \mathrm{PE}(\mathrm{M}) \\
& \quad=\mathrm{TIJKLM} / \dot{\mathrm{SIJKLM}}
\end{aligned}
$$

右辺の分母左辺一

$\mathrm{PA}(\dot{\mathrm{I}}) \cdot \mathrm{PB}(\mathrm{J}) \cdot \mathrm{PC}(\mathrm{K}) \cdot \mathrm{PD}(\mathrm{L}) \cdot \mathrm{PE}(\mathrm{M})$. $\mathrm{PE}(\mathrm{M}) \cdot \operatorname{SIJKLM}=$ TIJKLLM

このようにして兩辺の総和をとり, $\mathrm{PA}(\mathrm{I})$ を求め ればよい。しかし，この $\mathrm{PB}(\mathrm{J}) \cdot \mathrm{PC}(\mathrm{K}) \cdots \cdots$.... 等はこ の段階では未知なので,これへ(6) 式より求められた $\mathrm{PA}(\dot{\mathrm{I}})=\overline{\mathrm{PAI} K A}$ を代入する。

$\mathrm{PA}(\mathrm{I}) \cdot \overline{\mathrm{PBJ}} \cdot \overline{\mathrm{PCK}} \cdot \overline{\mathrm{PDL}} \cdot \overline{\mathrm{PEM}} \cdot \mathrm{KB} \cdot \mathrm{KC}$.

$$
\mathrm{KD} \cdot \mathrm{KE} \cdot \mathrm{SIJKLM}=\mathrm{TIJKLM}
$$

この総和をとると

$\mathrm{PA}(\dot{\mathrm{I}}) \cdot \mathrm{KB} \cdot \mathrm{KC} \cdot \mathrm{KD} \cdot \mathrm{KE} \cdot \Sigma^{4} \overline{\mathrm{PBJ}} \cdot \overline{\mathrm{PCK}} \cdot$ $\overline{\mathrm{PDL}} \cdot \overline{\mathrm{PEM}} \cdot \mathrm{SIJKLM}=\sum$ TİJKLM

$\mathrm{KA} \cdot \mathrm{KB} \cdot \mathrm{KC} \cdot \mathrm{KD} \cdot \mathrm{KE}=\mathrm{K}$ とすると

$\mathrm{PA}(\dot{\mathrm{I}})=\mathrm{KA} / \mathrm{K} \cdot \sum^{4} \mathrm{TI} J \mathrm{KLM} / \sum^{4} \overline{\mathrm{PBJ}}$.

$$
\overline{\mathrm{PCK}} \cdot \overline{\mathrm{PDL}} \cdot \overline{\mathrm{PEM}} \cdot \mathrm{SIJKLM}
$$

$\mathrm{PB}(\dot{\mathrm{J}}) \cdot \mathrm{PC}(\dot{\mathrm{K}}) \cdots \cdots$ \&同様にして計算する。 ここで,

$\mathrm{TA}(\dot{\mathrm{I}})=\sum^{4} \mathrm{TIJKLM}$

$\mathrm{TB}(\mathrm{J})=\sum^{4} \mathrm{TIJJKLM}$

$\mathrm{TC}(\dot{\mathrm{K}})=\sum^{4} \mathrm{~T} \dot{\mathrm{J} J K L M}$

$\mathrm{TD}(\dot{\mathrm{L}})=\sum^{4} \mathrm{TI} J K L M$ 


$$
\begin{aligned}
& \mathrm{TE}(\dot{\mathrm{M}})=\sum^{4} \mathrm{TIJKLM} \\
& \operatorname{PSA}(\dot{\mathrm{I}})=\sum^{\Delta} \overline{\mathrm{PA}(\dot{\mathrm{I}})} \cdot \mathrm{PB}(\mathrm{J}) \cdot \mathrm{PC}(\mathrm{K}) \cdot \mathrm{PD}(\mathrm{L}) \cdot \\
& \mathrm{PE}(\mathrm{M}) \cdot \operatorname{SIJKLM} \\
& \operatorname{PSB}(\dot{J})=\sum^{4} \mathrm{PA}(\mathrm{I}) \cdot \overline{\mathrm{PB}}(\dot{\mathrm{J}}) \cdot \mathrm{PC}(\mathrm{K}) \cdot \mathrm{PD}(\mathrm{L}) \cdot \\
& \text { PE }(\mathrm{M}) \cdot \text { SIJKLM } \\
& \left.\operatorname{PSC}(\dot{\mathrm{K}})=\sum^{4} \mathrm{PA}(\mathrm{I}) \cdot \mathrm{PB}(\mathrm{J}) \cdot \overline{\mathrm{PC}(\dot{\mathrm{K}}}\right) \cdot \mathrm{PD}(\mathrm{L}) \cdot \\
& \text { PE }(\mathrm{M}) \cdot \operatorname{SIJKLM} \\
& \operatorname{PSD}(\dot{\mathrm{L}})=\sum^{4} \mathrm{PA}(\mathrm{I}) \cdot \mathrm{PB}(\mathrm{J}) \cdot \mathrm{PC}(\mathrm{K}) \cdot \overline{\mathrm{PD}(\dot{\mathrm{L}})} \cdot \\
& \mathrm{PE}(\mathrm{M}) \cdot \text { SIJKL̈M }
\end{aligned}
$$

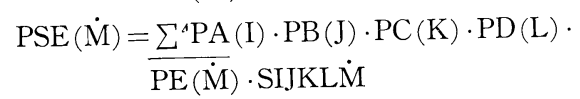

$$
\begin{aligned}
& \text { とおくと (11) 式は } \\
& \mathrm{PA}(\dot{\mathrm{I}})=\mathrm{KA} \cdot \mathrm{TA}(\dot{\mathrm{I}}) / \mathrm{K} \cdot \mathrm{PSA}(\dot{\mathrm{I}}) \\
& \mathrm{PB}(\dot{\mathrm{J}})=\mathrm{KB} \cdot \mathrm{TB}(\dot{\mathrm{J}}) / \mathrm{K} \cdot \mathrm{PSB}(\dot{\mathrm{J}}) \\
& \mathrm{PC}(\dot{\mathrm{K}})=\mathrm{KC} \cdot \mathrm{TC}(\dot{\mathrm{K}}) / \mathrm{K} \cdot \operatorname{PSC}(\dot{\mathrm{K}}) \\
& \mathrm{PD}(\dot{\mathrm{L}})=\mathrm{KD} \cdot \mathrm{TD}(\dot{\mathrm{L}}) / \mathrm{K} \cdot \mathrm{PSD}(\dot{\mathrm{L}})
\end{aligned}
$$
であるから左辺に (12) 式を代入して

$\mathrm{KA} \cdot \mathrm{KB} \cdot \mathrm{KD} \cdot \mathrm{KE} \cdot \mathrm{TA}(\dot{\mathrm{I}}) \cdot \mathrm{TB}(\mathrm{J}) \cdot \mathrm{TC}(\dot{\mathrm{K}}) \cdot$

$\operatorname{TD}(\dot{\mathrm{L}}) \cdot \mathrm{TE}(\dot{\mathrm{M}}) / \mathrm{K}^{5} \cdot \operatorname{PSA}(\dot{\mathrm{I}}) \cdot \operatorname{PSB}(\dot{\mathrm{J}})$.

$\operatorname{PSC}(\dot{\mathrm{K}}) \cdot \operatorname{PSD}(\dot{\mathrm{L}}) \cdot \operatorname{PSE}(\dot{\mathrm{M}})=\mathrm{TA}(\dot{\mathrm{I}}) \cdot$

$\mathrm{TB}(\dot{\mathrm{J}}) \cdot \mathrm{TC}(\dot{\mathrm{K}}) \cdot \mathrm{TD}(\dot{\mathrm{L}}) \cdot \mathrm{TE}(\dot{\mathrm{M}}) / \mathrm{K}^{4}$

$\operatorname{PSA}(\dot{\mathrm{I}}) \cdot \operatorname{PSB}(\dot{\mathrm{J}}) \cdot \operatorname{PSC}(\dot{\mathrm{K}})$

この式の中で未知数は $\mathrm{K}$ のみとなる。この計算は

(9) 式の PA(I) をI について総和をとり, $\overline{\mathrm{PA}(1)}$

$=\mathrm{KA}, \overline{\mathrm{PAI}}$ を代入する。

$\sum^{5} \mathrm{~K} \cdot \overline{\mathrm{PAI}} \cdot \overline{\mathrm{PBJ}} \cdot \overline{\mathrm{PCK}} \cdot \overline{\mathrm{PDL}} \cdot \overline{\mathrm{PEM}} \cdot \mathrm{SIJKLM}$

$$
=\sum^{5} \mathrm{TIJKLM}
$$

$$
\begin{array}{rr}
\text { より } & \mathrm{K}=\sum^{5} \mathrm{TIJKLM} / \sum^{5} \mathrm{SIJKLM} \\
\text { ここで }, & \mathrm{T}=\sum^{5} \mathrm{TIJKLM} \\
\mathrm{S}=\sum^{5} \mathrm{SIJKLM}
\end{array}
$$

と㧍くと

より求められる。

$$
\mathrm{K}=\mathrm{T} / \mathrm{S}
$$

なお，PA(I) におけるI とドットを付けたものは，

I の変域内のある数值に固定することを意味する。

また， $\Sigma^{4}=\Sigma \cdot \Sigma \cdot \sum \cdot \sum\left(\sum\right.$ をオペレッターとして

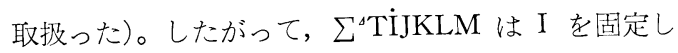
$\mathrm{JKLM}$ の 4 個について, それらの変域内で総和をと った。

\section{IV. 計算およびその結果}

\section{1) 計 算}

雪崩発生原因の固定要素と変動要素の調査の結果を 同一要素の斜面総数雪崩発生斜面数上に, 整理カード （表 IV-1）にまとめた。
この整理カードを，計算機の入力データとするた め, 千以上の桁で斜面総数を, 千未満の桁で雪崩発生 斜面数を表わすこれらを1つの数にし（表IV-2）を 大力データとした。

計算式は，III-2）で説明したように（表 IV-3）の 順序でフォートラン原語でブログラミングを行った。

\section{2) 計築の結果}

計算の結果を示したのが（表 $\mathrm{N}-4$ ) である。この表 に換げた数值は，雪崩が必ず発生する場合をとしたも ので, 斜面の要素と積雪深が判れば雪崩の発生する確 摔が判るようにまとめたものである。

例えば, 斜面の傾斜が 40 度以上で, 斜面の形が 1 の組合を持ち, 東向きで, 裸地または草地である斜面 が最も危険で, 積雪深 $4 \mathrm{~m}$ 以上になれば， $89.7 \%$ の 確率で雪崩が発生するという予測がだきる。

この分類方法は一般的であるから, 本調查地域に限 らず, 他地域でも利用可能であるし, 航空写真を入手 出来なくとも，実際に現地を観察することによっても 分類できるという便利さがある。

\section{V.あとがき}

この調査の主目的は, 既存の資料を使って, 積雪期 の航空写真が得られない地域の雪崩の発生を予測でき るようなシステムを作るということであり，結果とし は，一応目的を果したといえる。しかし残された問題 点为少くない。それらのいくかをあげこのシステムを 反省し今後の課題としていきたい。

雪崩発生の要素として, 変動要素と固定要素とに分 けたが, 航空写真の性質上変動要素の大部分が拾象さ れた。このことがどれだけ発生率に影響してくるかを 点検するために, 気象条件の異る地域でテストしなけ ればならない。また固定要素のとり方も, 単位斜面全 体を表現する項目と, 部分的でしか子再現性のそしい 項目が混ついるようなことがてる。判読そのものが主 観性の強いもので, 再現性が弱いものであるので, あ らかじめ判読基準のサンプルを作りできる限り客観性 の高いものにする必要がある。

本調査にあたって, 日本国有鉄道塩沢雪実験所長, 荘田博士から，種々御助言をいただいた。

北陸地方建設局, 上越国道工事事務所の皆様から終 始御便宜と御教示を仰いた。

ここに愿く御礼申し上げる次第である。

\section{参 考 文 献}

門村 浩: 航空写真測量と地形について 雪水 1 号 26 巻

日本鉄道施設協会：なだれ発生に対する航空军真 判読法の研究報告書. 


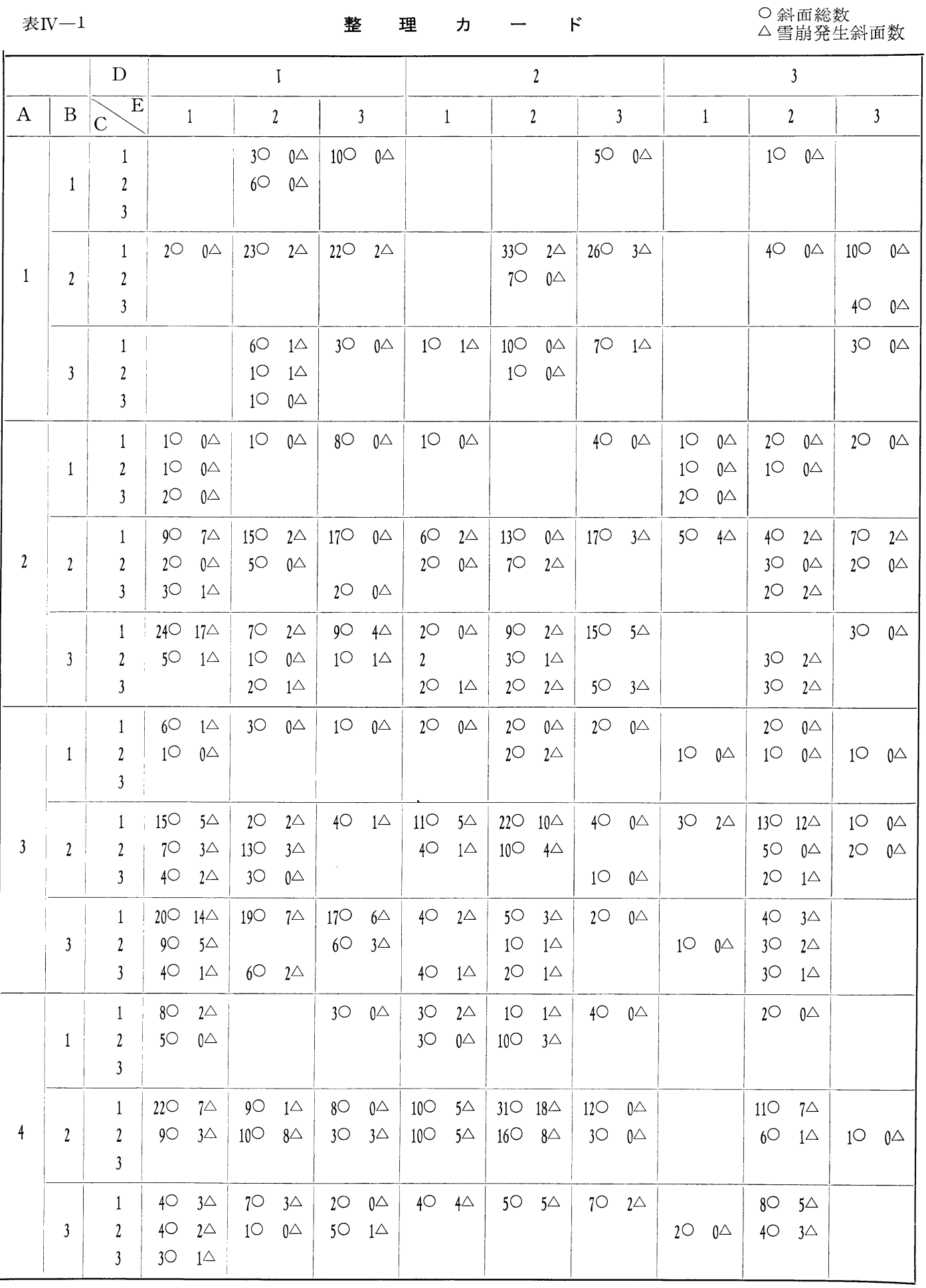


計算機 入力 ゙ー一タ

\begin{tabular}{|c|c|c|c|c|c|c|c|c|c|c|c|}
\hline \multirow{2}{*}{$\mathrm{A}$} & \multirow[b]{2}{*}{ B } & \multirow{2}{*}{$\frac{D}{\mathrm{E}}$} & \multicolumn{3}{|c|}{1} & \multicolumn{3}{|c|}{2} & \multicolumn{3}{|c|}{3} \\
\hline & & & 1 & 2 & 3 & 1 & 2 & 3 & 1 & 2 & 3 \\
\hline \multirow{9}{*}{1} & \multirow{3}{*}{1} & 1 & 0.0 & 3000.0 & 10000.0 & 0.0 & 0.0 & 5000.0 & 0.0 & 1000.0 & 0.0 \\
\hline & & 2 & 0.0 & 6000.0 & 0.0 & 0.0 & 0.0 & 0.0 & 0.0 & 0.0 & 0.0 \\
\hline & & 3 & 0.0 & 0.0 & 0.0 & 0.0 & 0.0 & 0.0 & 0.0 & 0.0 & 0.0 \\
\hline & \multirow{3}{*}{2} & 1 & 2000.0 & 23002.0 & 22002.0 & 0.0 & 33002.0 & 26003.0 & 0.0 & 4000.0 & 10000.0 \\
\hline & & 2 & 0.0 & 0.0 & 0.0 & 0.0 & 7000.0 & 0.0 & 0.0 & 0.0 & 0.0 \\
\hline & & 3 & 0.0 & 0.0 & 0.0 & 0.0 & 0.0 & 0.0 & 0.0 & 0.0 & 4000.0 \\
\hline & \multirow{3}{*}{3} & 1 & 0.0 & 6001.0 & 3000.0 & 1001.0 & 10000.0 & 7001.0 & 0.0 & 0.0 & 3000.0 \\
\hline & & 2 & 0.0 & 1001.0 & 0.0 & 0.0 & 1000.0 & 0.0 & 0.0 & 0.0 & 0.0 \\
\hline & & 3 & 0.0 & 1000.0 & 0.0 & 0.0 & 0.0 & 0.0 & 0.0 & 0.0 & 0.0 \\
\hline \multirow{9}{*}{2} & \multirow{3}{*}{1} & 1 & 1000.0 & 1000.0 & 8000.0 & 1000.0 & 0.0 & 4000.0 & 1000.0 & 2000.0 & 2000.0 \\
\hline & & 2 & 1000.0 & 0.0 & 0.0 & 0.0 & 0.0 & 0.0 & 1000.0 & 1000.0 & 0.0 \\
\hline & & 3 & 2000.0 & 0.0 & 0.0 & 0.0 & 0.0 & 0.0 & 2000.0 & 0.0 & 0.0 \\
\hline & \multirow{3}{*}{2} & 1 & 9007.0 & 15002.0 & 17000.0 & 6002.0 & 13000.0 & 17003.0 & 5004.0 & 4002.0 & 7001.0 \\
\hline & & 2 & 2000.0 & 5000.0 & 0.0 & 2000.0 & 7002.0 & 0.0 & 0.0 & 3000.0 & 2000.0 \\
\hline & & 3 & 3001.0 & 0.0 & 2000.0 & 0.0 & 0.0 & 0.0 & 0.0 & 2002.0 & 0.0 \\
\hline & \multirow{3}{*}{3} & 1 & 24017.0 & 7002.0 & 9004.0 & 2000.0 & 9002.0 & 15005.0 & 0.0 & 0.0 & 3000.0 \\
\hline & & 2 & 5001.0 & 1000.0 & 1001.0 & 0.0 & 3001.0 & 0.0 & 0.0 & 3002.0 & 0.0 \\
\hline & & 3 & 0.0 & 2001.0 & 0.0 & 2000.0 & 2002.0 & 5003.0 & 0.0 & 3002.0 & 0.0 \\
\hline \multirow{9}{*}{3} & \multirow{3}{*}{1} & 1 & 6001.0 & 3000.0 & 1000.0 & 2001.0 & 2000.0 & 2000.0 & 0.0 & 2000.0 & 1000.0 \\
\hline & & 2 & 1000.0 & 0.0 & 0.0 & 0.0 & 2002.0 & 0.0 & 1000.0 & 1000.0 & 0.0 \\
\hline & & 3 & 0.0 & 0.0 & 0.0 & 0.0 & 0.0 & 0.0 & 0.0 & 0.0 & 0.0 \\
\hline & \multirow{3}{*}{2} & 1 & 15005.0 & 20002.0 & 4001.0 & 11005.0 & 22010.0 & 4000.0 & 3002.0 & 13012.0 & 1000.0 \\
\hline & & 2 & 7003.0 & 13003.0 & 0.0 & 4001.0 & 10004.0 & 0.0 & 0.0 & 5000.0 & 2000.0 \\
\hline & & 3 & 4002.0 & 3000.0 & 0.0 & 0.0 & 0.0 & 1000.0 & 0.0 & 2001.0 & 0.0 \\
\hline & \multirow{3}{*}{3} & 1 & 20014.0 & 19007.0 & 17006.0 & 4002.0 & 5003.0 & 2000.0 & 0.0 & 4003.0 & 0.0 \\
\hline & & 2 & 9005.0 & 0.0 & 6003.0 & 0.0 & 1001.0 & 0.0 & 1000.0 & 3002.0 & 0.0 \\
\hline & & 3 & 4001.0 & 6002.0 & 0.0 & 4001.0 & 2001.0 & 0.0 & 0.0 & 3001.0 & 0.0 \\
\hline \multirow{9}{*}{4} & \multirow{3}{*}{1} & 1 & 8002.0 & 0.0 & 3000.0 & 3002.0 & 1001.0 & 4000.0 & 0.0 & 2000.0 & 0.0 \\
\hline & & 2 & 5000.0 & 0.0 & 0.0 & 3000.0 & 10003.0 & 0.0 & 0.0 & 0.0 & 0.0 \\
\hline & & 3 & 0.0 & 0.0 & 0.0 & 0.0 & 0.0 & 0.0 & 0.0 & 0.0 & 0.0 \\
\hline & \multirow{3}{*}{2} & 1 & 22007.0 & 9001.0 & 8000.0 & 10005.0 & 31018.0 & 12000.0 & 0.0 & 11007.0 & 0.0 \\
\hline & & 2 & 9003.0 & 10008.0 & 3000.0 & 10005.0 & 16008.0 & 3000.0 & 0.0 & 6001.0 & 1000.0 \\
\hline & & 3 & 0.0 & 0.0 & 0.0 & 0.0 & 0.0 & 0.0 & 0.0 & 0.0 & 0.0 \\
\hline & \multirow{3}{*}{3} & 1 & 4002.0 & 7003.0 & 2000.0 & 4004.0 & 5005.0 & 7002.0 & 0.0 & 8005.0 & 0.0 \\
\hline & & 2 & 4002.0 & 1000.0 & 5001.0 & 0.0 & 0.0 & 0.0 & 2000.0 & 4003.0 & 0.0 \\
\hline & & 3 & 3001.0 & 0.0 & 0.0 & 0.0 & 0.0 & 0.0 & 0.0 & 0.0 & 0.0 \\
\hline
\end{tabular}


表IV-3

\begin{tabular}{|r|r|r|r|r|r|}
\hline & \multicolumn{1}{c}{$\mathrm{A}$} & \multicolumn{1}{c}{$\mathrm{B}$} & \multicolumn{1}{c}{$\mathrm{C}$} & \multicolumn{1}{c}{$\mathrm{D}$} & \multicolumn{1}{c}{$\mathrm{E}$} \\
\hline & TijKLM & TijKLM & TijKLM & TiJKLi & TiJKLM \\
\hline 1 & 13.00000 & 12.00000 & 201.00000 & 127.00000 & 109.00000 \\
2 & 69.00000 & 149.00000 & 66.00000 & 111.00000 & 143.00000 \\
3 & 107.00000 & 127.00000 & 21.00000 & 50.00000 & 36.00000 \\
4 & 99.00000 & & & & \\
\hline
\end{tabular}

\begin{tabular}{|r|r|r|r|r|r|}
\hline & SijKLM & SijKLM & SijKLM & SijKLi & SijKLM \\
\hline 1 & 189.00000 & 115.00000 & 695.00000 & 453.00000 & 255.00000 \\
2 & 244.00000 & 557.00000 & 210.00000 & 375.00000 & 441.00000 \\
3 & 278.00000 & 295.00000 & 62.00000 & 139.00000 & 271.00000 \\
4 & 256.00000 & & & & \\
\hline
\end{tabular}

\begin{tabular}{|c|c|c|c|c|c|}
\hline & $\overline{\mathrm{PAi}}$ & $\overline{\mathrm{PBj}}$ & $\overline{\mathrm{PCK}}$ & $\overline{\mathrm{PDi}}$ & $\overline{\mathrm{PEM}}$ \\
\hline 1 & 0.06878 & 0.10435 & 0.28921 & 0.28035 & 0.42745 \\
2 & 0.28279 & 0.26750 & 0.31429 & 0.29600 & 0.32426 \\
3 & 0.38489 & 0.43051 & 0.33871 & 0.35971 & 0.13284 \\
4 & 0.38672 & & & & \\
\hline
\end{tabular}

\begin{tabular}{|c|r|r|r|r|r|}
\hline & PSA (i) & PSB $(\dot{\mathrm{J}})$ & $\operatorname{PSC}(\dot{\mathrm{K}})$ & $\operatorname{PSD}(\dot{\mathrm{L}})$ & $\operatorname{PSE}(\dot{\mathrm{M}})$ \\
\hline 1 & 0.07355 & 0.09902 & 1.51751 & 1.18851 & 1.00740 \\
2 & 0.54754 & 1.20655 & 0.64510 & 0.80216 & 1.16509 \\
3 & 0.99730 & 1.10243 & 0.24539 & 0.41733 & 0.23551 \\
4 & 0.78962 & & & & \\
\hline
\end{tabular}

$\{$ TIJKLM : 同一要素同階級区分の雪崩発生総数 SIJKLM： " " 斜面総数

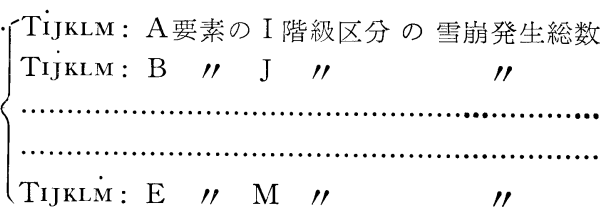

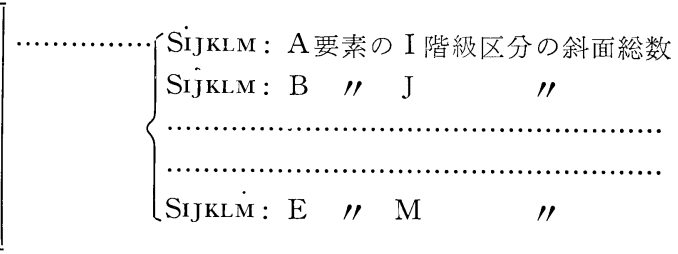

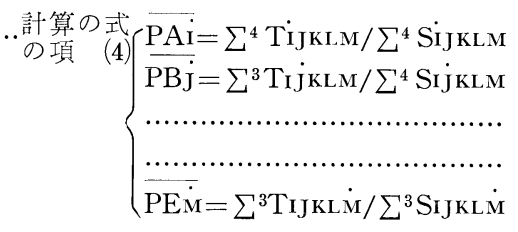

\begin{tabular}{|l|l|}
\hline $\mathrm{K}$ & 119.60119 \\
\hline
\end{tabular} $\cdot \mathrm{K}=\sum^{4}{ }^{\top}$ TлjkLM $/ \Sigma^{4} \operatorname{PSA}(\mathrm{I})$

\begin{tabular}{|c|c|r|r|r|r|}
\hline & $\mathrm{PA}(\dot{\mathrm{I}})$ & $\mathrm{PB}(\dot{\mathrm{J}})$ & $\mathrm{PC}(\dot{\mathrm{K}})$ & $\mathrm{PD}(\dot{\mathrm{L}})$ & $\mathrm{PE}(\dot{\mathrm{M}})$ \\
\hline 1 & 0.10165 & 0.10573 & 0.32029 & 0.25048 & 0.38670 \\
2 & 0.29796 & 0.27621 & 0.26885 & 0.34247 & 0.33276 \\
3 & 0.34527 & 0.41467 & 0.24235 & 0.36034 & 0.16978 \\
4 & 0.40539 & & & & \\
\hline
\end{tabular}

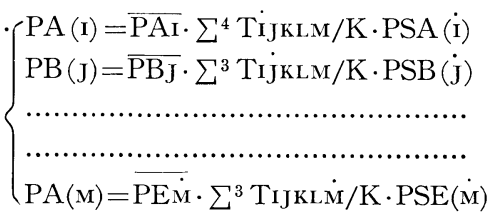




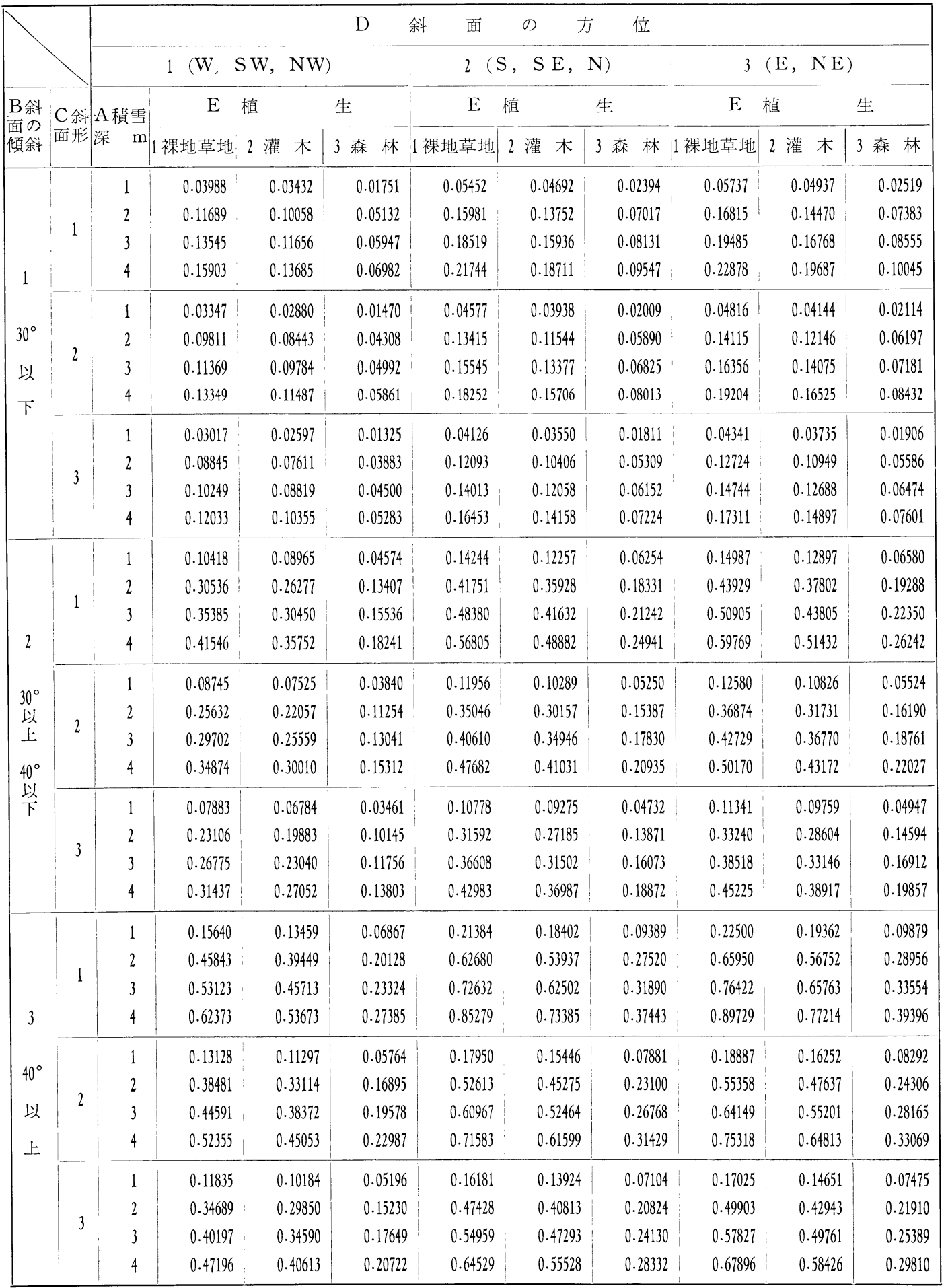

